
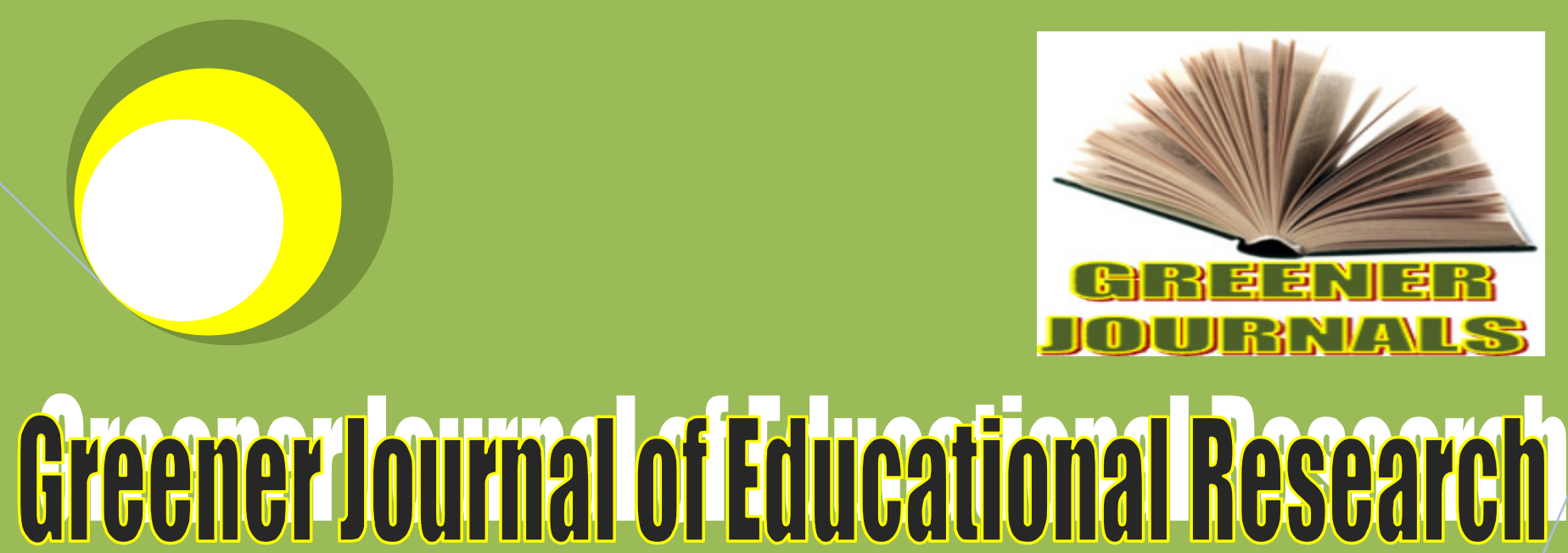

ISSN: 2276-7789 Impact Factor 2012 (UJRI): 0.7230 ICV 2012: 6.05

\title{
An Analysis on How \\ Demotivated Teachers \\ Affect O-Level Pass \\ Rate
}

By

Chingombe Shamiso Iline 


\title{
An Analysis on How Demotivated Teachers Affect O-Level Pass Rate \\ Chingombe Shamiso lline
}

Faculty of Education, Department of Educational Foundations: Great Zimbabwe University: Zimbabwe.

Email: schingombe21@gmail.com

\begin{abstract}
The purpose of this study was to assess the extent to which demotivated teachers contribute to the poor 0 - level pass rate. The researcher was alarmed by the failure rate recorded in the daily newspaper. The Herald of 6 February 2013 highlighted that the poor academic performance of the pupils was blamed on the teachers. In a bid to ascertain this claim the researcher carried out the study to establish its authenticity. A descriptive survey was used as the research design. For triangulation purpose the data was collected through interviews, questionnaires and document analysis, focusing on six secondary schools in Harare. Interviews were conducted to school heads and twenty parents while the questionnaires were administered to twenty teachers. Document analysis of ' $O$ ' level results was done to ascertain the pass rate in schools. The results of the study have shown that most schools recorded low pass rate. Some teachers outlined that due to economic hardship they are resorting to some extra jobs in a bid to supplement their income which compromised the teaching and learning. However, they also shifted the blame to the parents whom they accused of not assisting their children with homework. They pointed out that parents are not fully supporting their children by giving them the resources to enhance effective learning. The paper makes a significant contribution to the field of education in that it brings to light the grievances from the teachers and parents. This has implications for policy makers who should address the plight of teachers in ways that enable them to maintain the dignity of their profession. It also enhances the teachers to execute their duties meticulously in order to improve the pass rate in schools.
\end{abstract}

Keywords: Devote, incentives, demotivated, performance, supplement.

\section{INTRODUCTION AND BACKGROUND}

The pass rate in schools has been a cause of concern to the parents. The Herald of 6 February 2013 highlighted that the decline in O-level pass rate was blamed on demotivated teachers. The teachers influence the mood of students, teach them the positives of life and nurture them into stars. Thus, if teachers are motivated they are bound to execute their duties meticulously. Luthans (1995) recommends that for the workers to be committed the set goals ought to be rewarding. The teachers need to be remunerated so that their basic needs are met hence motivate them as they will be teaching. The $\mathrm{H}$ - Metro of 07 March 2010 reported that Dr Mahere, the permanent secretary in the Ministry of Education Arts, Sports and Culture, reiterating the need to reasonably remunerate teachers so that they have some respect in the society. This remark was made as a way of motivating the teachers to enhance effective teaching to promote high pass rate. Due to this background, the researcher was motivated to carry out a survey to ascertain the factors that contributed to the decline of the pass rate in schools.

\section{Research Questions}

The following research questions underpinned the study:

1. What motivational factors affect the teachers' execution of duty?

2. To what extent do teachers contribute to pass rate in schools?

3. What role do parents play to enhance the effective learning of their children? 


\section{Research objectives}

The study was guided by the following objectives:

$>$ To find out how teachers execute their duties to enhance effective teaching and learning.

$>$ To identify the relationship between academic performance and teacher motivation.

\section{RESEARCH METHODOLOGY}

The research design for this study is a mixed- methods approach which uses both qualitative and quantitative methods (Trochim 2006). Quantitative data is collected through the questionnaires. Qualitative data is obtained from the interviews. Morrison, Manion, and Cohen (2011) purport that educational researchers make use of both qualitative and quantitative methods to promote understanding of the teaching and learning. The research instruments used were the questionnaires, the interview and document analysis. The researcher is going to use purposive sampling. Miles (2001) highlights that purposive sampling enhances the researcher to get information from key informants who are knowledgeable and have information pertaining to the phenomena that the researcher is investigating. The questionnaires are going to be personally administered by the researcher to the respondents. McMillan and Schumacher (2010) postulated that interviews can be done face to face or through the telephone. In this study face to face interviews were done with the school heads and the parents. The sample for the study comprised of thirty teachers, six school heads and twenty parents. The researcher sought consent from the respondents before the instruments were administered to the respondent.

\section{THEORETICAL FRAMEWORK}

This study on teacher motivation is guided by the Aristotelian philosophy and Thorndike's "Law of effect" . Motivation is generally defined as a force, stimulus, or influence that moves a person or organism to act or respond (Deci, 1993). Thus, motivation propels or facilitates people to do the things that they do. Incentives and rewards are motivational reinforcements considered to be derived from external sources. Most of the time, teachers motivate students to do their best in the classroom, but there are times when teachers also need to be motivated in order to provide the best instruction (Bee and Boyd, 2004). Therefore, teachers need to be inspired and keep their morale high in order to enable them to execute their duties meticulously. Snowman, McCown and Biehler (2009) state that positive reinforcement involves strengthening a target behaviour by repeatedly presenting a favourable stimulus. Thus behaviours with pleasant outcomes are repeated; those with unpleasant outcomes are shunned. Edward Thorndike suggested that responses closely followed by satisfaction will become firmly attached to the situation and therefore more likely to reoccur when the situation is repeated (Kopp and Krakow,2009). In concurrence, Mangal (2004) postulate that when a response is accompanied by a satisfying state of affairs that connection's strength is increased whilst an annoying state's strength is decreased. Conversely, if the situation is followed by discomfort, the connections to the situation will become weaker and the behavior of response is less likely to occur. If a particular behavior is followed by a desirable consequence or a reward, that behavior is more likely to happen again in the future. This reflects that if teachers are satisfied the chances for them to execute their duties meticulously are very high.

Banks (1997) propounds that Aristotle views motivation as the result of an 'appetitive' function, which always operates relative to some outcome or end. Thus, what the teachers get at the end of the month affects how they execute their duties. Barker (1994) highlights that in Aristotle's view, it was 'the real or the apparent good', some anticipated consequence, or image of "what is to come" derived in reference to what is present, that simulated a living organism to pursue it (if positive) or avoid it (if negative). The remuneration given to teachers has positive or negative effects. People will be stimulated to do certain behaviours in accordance with what they are given as a reward. In support of this view, Freire (1996) highlights that an action is done for the sake of something. He further talks about the teleology which points out that the good that motivates the agent is the end. There is an assumption that teachers who are well remunerated have higher chances of executing their duties earnestly. The Aristotelian perspective of human motivation stipulates that whatever is done by every individual, there is a driving force behind every action (Sockett, 1993). From this view the way people execute their duties is influenced by the value that they attach to anticipated consequences. Positive expectations, for instance, can push people to put out extra effort in the hope of reaching some desired outcome. Expected consequences that are perceived as "negative," on the other hand, will lead to either avoidance or apathy (Fullan, 1999). 


\section{Motivational factors that affect the teachers' execution of duty}

Motivation attempts to explain why people behave in a certain manner (Elliot, Elliot and Kratochwill, 1993). The way humans are motivated necessitates their actions and commitment to differ substantially. Moorhead and Griffin (1995). Deci (1993) outline that the heart of motivation is to give people what they really want most from work. Thus, the more the employers are able to provide what their employees want, the more the productivity and quality service will be delivered by them.

Employees can accomplish the organisational goals provided their extrinsic desires are met by their employers. This reflects how external forces stimulate or drive the teachers' motivation. Thus, the key to understand the process of motivation lies in the meaning of and relationship between needs, drives and incentives (Donald, Lazarus and Lolwana, 2010).

Monetary rewards systems do play an important role in motivating employees. The Herald of 2 November 2011 cites Dr Sikhanyiso Ndlovu, the Secretary for Education recommending that if people need teachers, they must make sure that they stay motivated. In concurrence, Hoy, Bayne-Jardine and Wood (2000) stipulate that if teachers are motivated, they direct their energy in formal lessons. Thus, if the teachers are motivated, they try hard to cover the syllabus before pupils write the examinations.

Most teachers try to improve their standard of living by engaging in various activities to earn an extra dollar. Pinder (2008) noted that workers engage in secondary activities after work to supplement what their income. As a result of engaging in private tuition, there is a possibility that teachers will exhaust their energy in conducting these extra lessons at the expense of formal lessons. They are engaging in part-time jobs during and after school hours. This makes the teaching profession to been looked down upon to the extent that it is no longer accorded the respect it deserves. As a result, the teachers no longer have the pride in their profession.

\section{How do parents contribute to the effective learning of their children?}

Parents are the first on-going educators of their children; hence they should support their learning when they are at home. Pupils usually feel more confident if they get encouragement and support from their parents. Parental effort is consistently associated with higher levels of achievement and the magnitude of the effect of parental effort is substantial (Kosslyn and Rosenberg, 2006). This shows that it is not only the role of the teacher to enhance remarkable performance of the learners. Thus, the parents and the teachers should work hand in glove towards pupils' achievement. They enhance complementation of the teachers' expertise and skills. Bee and Boyd (2004) highlighted that parents are involved in their children's work because they feel they should be involved. When there is collaboration between families and the school, children tend to perform better in school work. There is an all-round benefit where there is positive relationship between parents and teachers. Thus, all parents who want the best out of their children are obliged to supervise their children's homework.

\section{FINDINGS AND DISCUSSION OF FINDINGS}

The findings of the study were as follows:

$>$ Most parents are not assisting their children with homework.

$>$ It was found out that there is a relationship between students' poor academic performance and teacher demotivation.

$>$ Teachers engaged in secondary jobs to supplement their income.

$>$ The salary increment can help to boost the morale of teachers.

The findings revealed that most of the teachers were not happy with their remuneration. As a result, they ended up engaging in secondary activities which assist them to bring bread and butter at their tables at the end of the day. In view of this, Pinder (2008) notes that teachers engage in secondary activities after work to supplement what their income . Thus one cannot ignore the fact that teachers are not satisfied with their salaries. Therefore to boost the teachers' morale they should stay motivated so that they remain devoted to their duties. Some teachers highlighted that they cannot afford to own their houses. There were some indications that teachers are sometimes embarrassed by their landlords when they are demanding the rentals. They also grieved that the utility bills demanded by the landlords are sometimes not realistic. It was noted that some teachers have resorted to selling Aloe Vera products in order to boost their monthly income. A respondent outlined that she sometimes faked being sick so that she could afford herself enough time to meet her clients whom she is obliged to see during business hours. One teacher revealed that she is now a supervisor for selling Aloe Vera products. She indicated that she is now being paid five 
hundred dollars per month for selling and recruiting down liners for Aloe Vera products. Some teachers were also selling Angels products to supplement her income. There were some indications that sometimes teachers absconded afternoon lessons to recruit some down liners. Some teachers indicated that they have resorted to borrowing money from the banks. They highlighted that they are now getting deductions from Post Office Savings Bank, BancABC and CBZ Bank. They complained that after the loan deductions their salaries are no longer able to sustain them for the whole month.

Some school heads complained that some teachers are engaging in private college tuition after work and during weekends. This resulted in cases where some teachers ended up absconding school afternoon activities. Some teachers are reported to be engaging in private tutoring at the school premises. This compromises teaching during the normal school time. Extra lessons are no longer done to benefit the weaker students. Instead, they are now being done as a way of raising money by most teachers.

Teachers were however, complaining that most parents are also not playing their part in the learning of their pupils. They highlighted that some parents do not assist their children with homework. Parents should also realise that it takes two to tangle. That is, there ought to be collaboration between the parents and the teachers so that the children will obtain good results. Parents should also realise that they are also stakeholders in the teaching and learning of their children. They have a remarkable role to play towards the goal attainment of their children. They need to work hand in gloves with the teachers towards the education of their children. They should bear in mind that their children mean everything to them. They ought to prove it by being involved in all the school activities. Their contribution can be noted by attending consultation days so that they can discuss with the teachers how best to assist their children. Parents ought to be co-operative by providing their children with what the entire teachers request for the benefit of their children's learning. There is need for both the teachers and parents to work together towards the attainment of goal achievement by the pupils. In response, some parents indicated that it is quite cumbersome to assist their children since they have more than one child attending school. They argued that sometimes they will be very tired after work such that by the moment they arrive home, they would need to rest. Some parents indicated that they will be busy concentrating on their studies and, therefore, they cannot spare time to assist their children. One parent said, "I opted to pay someone to assist my child with the homework because I do not have time to make a follow-up." Another parent said that, "honestly speaking, the kids are not my biological ones so there is nowhere I should devote my spare precious time towards that."

\section{Document Analysis}

The table below shows 'O' level results for 2012 which were analysed to ascertain whether teacher demotivation contributes to the failure rate.

\begin{tabular}{|l|l|l|l|l|l|l|}
\hline \multirow{3}{*}{ YEAR 2012} & \multicolumn{5}{|l|}{ PERCENTAGE PASS RATE (\%) } \\
\cline { 2 - 7 } & School A & School B & School C & School D & School E & School F \\
\cline { 2 - 7 } & $45 \%$ & $33 \%$ & $40 \%$ & $55 \%$ & $50 \%$ & $48 \%$ \\
\hline
\end{tabular}

Table 1: Percentage pass rate for 2012: 'O' level results

Generally, results in Table 1 show that the pupils' performance is not pleasing in all the six schools. This can be attributed to the teachers' demotivation. Some of the parents complained that they were not happy at all. They complained that how can their children fail dismally yet they are supplementing the teachers' salaries by giving them incentives. They indicated that sometimes they go an extra mile by giving them some goodies such as basic commodities. Some parents were fuming that they were really disappointed with the 2012 O-level results. They recommended that teachers ought to work hard since parents were subsidising their income. One of the parents complained that teachers should not use their cell phones during working hours. He said, "nematone enyu akauya aya, matichaya ava kutoita ngano half of the lesson vana vakamumirira." It literally means, with the use of net one lines (which has more free talking bonus time), teachers spend half of the lesson discussing petty issues over the phone whilst the pupils are awaiting for the lesson delivery. Whilst the cell phones are used as a form of communication they should not be prone to abuse. Teachers should use their cell phones when there is a genuine need to do so. They ought not inconvenience their pupils.

There was a complaint from one parent that, "the school used to perform quite well and I am one of its former students. That is why I opted to send my child here." There was a strong feeling from one parent that teachers should consider teaching to be their core business. He further complained that they should be discouraged from engaging in their personal activities which disrupt the proper teaching and learning of the pupils. 


\section{RECOMMENDATIONS}

The following recommendations were made:

$>$ The Government should give viable salaries to the teachers.

> The Ministry of Education, Sport, Arts and Culture should charge the teachers who are violating Statutory Instrument Number 1 of 2000 which prohibits civil servants from engaging in private business.

$>$ Parents should be involved in the teaching and learning of their children.

$>$ The Ministry of Education, Sport, Arts and Culture should prohibit teachers from using cell phones during working hours.

\section{ACKNOWLEDGEMENTS}

I would like to thank the following people for the support and assistance offered throughout the study. Special thanks go to my husband Agrippa Chingombe for the moral support. Sincere gratitude goes to Emmanuel Makado for editing the paper.

\section{REFERENCES}

Banks, J. A. (1997) Educating Citizens in a Multicultural Society: New York Teachers' College Press

Barker, R. E. (1994). Philosophies of Education. College Press: Harare

Bee, H. and Boyd, D. (2004). The Developing Child (10th Edition). Illinois: Pearson Education.

Deci E. L. (1993). Extrinsic Rewards and Intrinsic Motivation in Education. Plenum Press: New York

Donald, D., Lazarus, S. and Lolwana, P. (2010). Educational Psychology in Social Context: Ecosystemic Applications in Southern Africa ( $4^{\text {th }}$ Edition). Cape Town: Oxford University Press

Elliot, J. F., Elliot, S. N. and Kratochwill, T. R. (1993). Educational Psychology. Effective_Teaching and Effective Learning. Wm. C. Brown Communications Inc. USA.

Freire, P. (1996). Pedagogy of The Oppressed, $2^{\text {nd }}$ Ed. London: Penguin.

Fullan, M. (1999). The New Meaning of Educational Change $2^{\text {nd }}$ Ed. Cassel: London.

Hoy, C. Barne-Jardine, C. and Wood, M. (2000). Improving Quality in Education. London: Falmer Press.

Kosslyn, S. M. and Rosenberg, R. S. (2006)._Psychology in Context ( ${ }^{\text {rd }}$ Edition). New Delhi: Dorling Kindersley (India) Pvt Ltd.

Luthans, F (1995). Organisational Behaviour 7th Ed, New York, McGraw Hill.

Mangal, S.K (2004)Advanced Educational Psychology 2nd Edition . India, Prentice Hall of India Pvt Ltd.

Miles,J (2001) Research Methods and Statistics. Great Britain. Bell and Bain Ltd

McMillan, J.H \& Schumacher, S (2010) Reaearch in Education. Evidence- Based Inquiry

Morrison, K, Manion, L. And Cohen, L. (2011) Research Methods in Education Great Britain: Ashford Colour Press Ltd

Pinder, C.C (2008) Work Motivation in Organisational Behaviour 2nd Edition. New York. Psychology Press

Moorhead, G. and Griffin, R.W. (1995). Organisational Behaviour. Boston: Houghton and Mifflin.

Sockett, H. (1993). The Moral Base for Teacher Professionalism._New York: Simon \& Schuster Publishers

The Director's Circular 36 of 2006

The $\mathrm{H}$ - Metro of 07 March 2010

The Herald, 14 March 2011

The Herald, 2 November 2011

The Herald, 6 February 2013 